\title{
Design and Implementation of Image Resource Library of Chinese Kunqu Opera Art
}

\author{
Bin Shao ${ }^{1}$, Guorong Ding ${ }^{1}$
}

${ }^{1}$ College of Arts and Media, Suzhou University of Science and Technology, Suzhou, 215011, China

Keywords: Art education; Resource library; Kunqu opera

\begin{abstract}
Construction of national art image resource library is an important content combining science and technology with culture and art education in the information age. Kunqu opera serves as a conscious rediscovered art resource of national culture. Its subjectivity regression in school art education is inevitable. This paper tries to propose construction scheme and implementation route of construction of national education resource library of Chinese Kunqu opera.
\end{abstract}

\section{Kunqu opera art protection project reflects cultural self-consciousness of national will}

Under the background of national rapid development of cultural undertaking in recent years, Kunqu opera art has gained a large quantity of plentiful and substantial achievements under the support of a series of practical works of central and local governments represented by "rescue, protection and support of Kunqu opera art” of Ministry of Culture. In terms of stage art, a large group of traditional highlights from operas are rescued; in terms of talent cultivation, a large group of young actors are cultivated; in academic circle, a large group of excellent compilation achievements are organized, represented by Wu Xinlei’s Chinese Kunqu Opera Dictionary, Series Books on Kunqu Opera and Traditional Culture Research edited by Traditional Chinese Opera Graduate School of Chinese Art Research Institution and Oral History of Kunqu Opera presided over by Wang Ankui. The researches are conducted from the perspective of theory and culture multi-dimension. A batch of academic research results on Kunqu opera form. Six theaters and one institute (North Kunqu Opera Theater, Shanghai Kunqu Opera Troupe, Jiangsu Kunqu Opera Theater, Zhejiang Kunqu Opera Theater, Jinagsu Suzhou Kunqu Opera Theater, Hunan Kunqu Opera Troupe and Zhejiang Yongjia Kunqu Opera Training Institute) will excavate and settle a large number of excellent, traditional and endangered Kunqu operas annually.

Secondly, newly prepared operas. The reason why Kunqu opera art occupies an important position in national culture is that Kunqu opera art deposits abundant artistic connotation. Art means are diversified. Art forms are exquisite. The expressive force, infectivity and infectivity own unique advantages. Meanwhile, the dialectical relationship among protection, inheritance and development is grasped. Excellent innovative operas are prepared. UNESCO explicitly points out that intangible cultural heritage is mainly protected by continuous innovation and practice (use) of those (representatives) creating, maintaining and transforming such heritage. They aim to promote inheritance and development of Kunqu opera and better press close to the age and audiences.

Finally, literature. In the endless development process of Kunqu opera, very rich precious literatures, scripts, music scores, pictures and costumes etc. are left. China's Kunqu Opera Museum and Chinese National Academy of Arts etc. collect, settle, protect and utilize these cultural relics of Kunqu opera with historic value.

To some extent, a development history of Kunqu opera is a series biography of Kunqu opera artists which serves as a link between past and future. Artistic practice of generations of Kunqu opera artists forms the development history of Kunqu opera art. To inherit the experience of famous Kunqu opera artists, the experience of famous Kunqu opera writers, musicians and performing artists is recorded, settled, edited and published.

Chinese Kunqu opera researches mainly move towards two tracks: 1) traditional research fields of Kunqu opera: literature and art; the researches on famous experts talking about art, historical essay on opera, singing method and historical data of Kunqu opera gain important development; 2) extensive 
interdisciplinary field: research perspectives and methods on folklore, sociology, history and communication continuously penetrate in researches on Kunqu opera so that researches on Kunqu opera present various colors.

\section{Tour performance of Kunqu opera classics in universities highlight subjectivity regression of art education}

Kunqu opera has a long history in university education. In 1905, opera master Wu Mei left for Soochow University to teach. He "gives directions on Gong and Shang and takes a bamboo flute in classroom” (Tang Guizhang Shortened Form of Lily Magnolia Flowers for the $100^{\text {th }}$ birthday of Mr. Qu). He started to regard Kunqu opera as a kind of knowledge and made it enter higher institution. But so far, the researches on Kunqu opera education in universities are still in the starting stage, so they still remain to rise (there is no special works). Except Zhou Qin’s Kunqu Opera Class I Teach, and Kunqu Opera Education Suzhou University as well as Ye Changhai's Kunqu Opera and Education, there are few relevant works. The researches on Kunqu opera education in universities are far behind educational practice of Kunqu opera in universities.

Chinese and oversea university tour performance of Peony Pavilion of youth version brings young audiences and more educational practice activities of Kunqu opera. For example, "Kunqu opera inheritance plan of Bai Xianyong in Peking University" in 2009 echoes with "Kunqu opera inheritance plan of Bai Xianyong in Suzhou University” in 2010. They enrich the form of Kunqu opera education in Chinese universities. It is beyond all doubt that with the cultivation and rise of young audience group of Kunqu opera, researches on Kunqu opera education in Chinese universities will gradually arouse more extensive attention.

\section{Kunqu opera art education resource library expands space-time field domain of Kunqu opera art education}

With the development of digital image technology and multimedia database technology, image information database construction becomes a new growth point of Kunqu opera art research, inheritance and development. A representative project is Grand Ceremony of Kunqu Opera Art which is lasted for 5 years and presided over by Traditional Chinese Opera Graduate School of Chinese Art Research Institution. This project breaks through traditional book compilation form of integrated form. With the help of text literature, audio-visual materials and picture information, Chinese Kunqu opera art remains are displayed vividly and three-dimensionally in a multi-level way. There are also other projects for public welfare subsidized by folk social force such as "a hundred kinds of Kunqu operas and taking about operas by great masters". The government, educational circle and social force jointly drive construction of Kunqu opera image resources. The image is utilized to protect, rescue and utilize Kunqu opera.

The combination of information technology and traditional culture generates interactive fusion effect of culture, science and technology. Kunqu opera stage performance, figures' dictation, classroom recording, comments on dramatists, academic discussion and cultural relic literature and substance remains are shot and kept to establish Kunqu opera image archives. Meanwhile, structural management of image data is conducted to set up Kunqu opera image database and then provide Kunqu opera image retrieval service platform so as to provide significant information about Kunqu opera information data for performance and research of governmental cultural management sector, troupe, opera club, schools and R\&D institutions.

The research on Kunqu opera image database is different from text-dominated literature research, and has its peculiarity. It is fifferent from record files who can be kept through description and records. It is presented with "image in active state" and retrieved with "data coding". Due to the deficiency of image, 600-year Kunqu opera art was once lost from our civilization history. To cherish and settle valuable "culture heritage" of Chinese nation, we should take full advantage of modern science and technology to "perpetually consolidate" artistic charm of Kunqu opera so as to construct 
Kunqu opera art and culture base for later generations and enhance cohesive force and influence of Chinese culture.

At present, image database in Kunqu opera art field is still in the initial stage of image archive construction and fails to go deep into core construction and application stage of image database. With regard to technical research and method study of Kunqu opera image database construction, the relevant papers are scarce. Image data with academic value cannot be effectively retrieved. Even, open and shared service applications are not realized. With a comprehensive survey of Chinese and oversea research status, the characteristics of image database construction of Kunqu opera art are as follows:

1). In terms of resource form, there are many image records and few structural data;

2). In terms of technological development, there is much warehouse storage and little intelligent retrieval;

3). In terms of communication service, there is much internal exclusive sharing and little sharing;

4). In terms of content selection, there are many videos of famous actors and few videos of opera scholars.

\section{Construction frame of Kunqu opera art education resource library}

Chinese Kunqu opera art image database plans to carry out relevant database construction and research of Kunqu opera activities, dictation and digital image data of cultural relic literature.

Research contents of this stage include the following aspects:

Firstly, construction of Kunqu opera image database, including stage performance, Kunqu opera education, academic activity and mass activity etc. (Because of active performance inheritance peculiarity of Kunqu opera heritage, stage performance is listed separately). Stage performance involves troupe performance recording with copyright. Bai Xianyong’s Kunqu opera inheritance plan, performance image of traditional highlights from operas as well as performance image of traditional highlights from operas of troupes and training institutions. The others are shown in the figure.

Secondly, construction of dictation image database of Kunqu opera, including Kunqu opera performing artists, performers, experts, scholars and series dictation biography of opera experts and friends. To some extent, dictation image is an important constituent part of Kunqu opera art development history.

Thirdly, construction of digital image of Kunqu opera literature, including precious cultural relic literatures, such as music score, script, picture, book and letter. These are indispensable precious deposits of Kunqu opera research.

The key points of content construction of Kunqu opera art image database lie in two aspects: 1) image database of Kunqu opera sage performance, including stage practice and dictation history of actors, performers and relevant figures; 2) original places of Kunqu opera and cultural relic remains; the key point of technical researches on Kunqu opera art image database lies in how to develop network video oriented to multi-terminal application.

General recording methods of research data of traditional Kunqu opera art are classified into two types: written and stage records. The difficulty lies in diversified three-dimensional recording and structural image data so as to maker it suitable for comprehensiveness character of Kunqu opera art inheritance.

(1) In the aspect of time, the active contents of Kunqu opera need to be tracked and recorded. This needs persistent manpower, material resources and time. Meanwhile, Kunqu opera art owns profound connotation, so technology developers also need to own certain Kunqu opera knowledge and closely operate with other members in order to develop database system suitable for art characteristics of Kunqu opera;

(2) In the aspect of space, the data are disperse. Although extensive collection of data is conducted during investigation, it is hard to pursue completeness;

(3) Technologically, data storage and recording means are diversified, with isomerous form and complex technology. 
Stage performance of Kunqu opera art, artists' interview, school education, image data of opera club activity and image of cultural relics and literature have isomorphism in terms of data content, but have isomerism in terms of data technology. Image data storage, retrieval and release oriented to different terminals are the starting point and return of integrating multivariate data.

In one word, Kunqu opera as a representative of intangible cultural heritage in the world reflects cultural self-consciousness of state and nation in terms of cultural transmission, also achieves subjectivity regression of national art education content in university art education, fully applies modem informatization technology to set up national Kunqu opera art education resource library, achieve more extensive space-time range of Kunqu opera, radiate charm of Chinese art and establish aesthetic base of Chinese culture.

\section{Acknowledgments}

This paper is a part of general project of humanistic and social science research of Ministry of Education - image database system construction of Kunqun opera intangible cultural heritage (project No.: 11YJAZH076) and the topic of "the $12^{\text {th }}$ Five-year Plan" of Jiangsu Science of Education Study on tacit knowledge in Kunqu opera (project No.: T-c/2013/015).

\section{References}

[1] Wu Xinlei, Chinese Kunqu Opera Dictionary. Nanjing: Nanjing University Press, 2002.5

[2] Sun Chongtao, Opera literature. Taiyuan, Shanxi Education Publishing House, 2008.2

[3] Fu Jin, Torch Conveying, Theory and practice of intangible cultural heritage. Beijing: China Social Sciences Publishing House, 2008.6

[4] Zhou Qin, Suzhou Kunqu opera. Suzhou: Suzhou University Press, 2004.4

[5] Wang Yaoxi, Digitization of national cultural heritage. Beijing: People's Publishing House, 2009.5.

[6] David Dagan Feng, Multimedia information retrieval and management. Translated by Liu Xiaodong. Beijing: Tsinghua University Press, 2009.11. 